\title{
SÁNCHEZ COLLANTES, Sergio, El pueblo a escena. Republicanismos y tradición democrática en la Asturias del siglo XIX
}

\author{
Oviedo, RIDEA, 2019, 768 pp.
}

\author{
Rafael Rodríguez Valdés \\ Universidad de Oviedo, España \\ rafaelrv@ayto-corvera.es
}

Cómo citar esta reseña: RODRÍGUEZ VALDÉS, Rafael (2022). Sánchez Collantes, Sergio, El pueblo a escena. Republicanismos y tradición democrática en la Asturias del siglo XIX. Pasado y Memoria. Revista de Historia Contemporánea, (24), pp. 389-392, https://doi.org/10.14198/PASADO2022.24.20

Este libro, merecedor del XXXIII Premio de Investigación Juan Uría Ríu, contiene parte de la tesis doctoral del historiador asturiano Sergio Sánchez Collantes, actualmente profesor en la Universidad de Burgos y autor de distintas monografías y de decenas de artículos sobre el mismo campo de investigación.

El pueblo a escena se divide en tres grandes partes. La primera de ellas, «Acercamiento a los orígenes y la propagación del republicanismo en Asturias (1789-1874)», abarca 275 páginas y está subdividida en tres grandes bloques. El primero de ellos, dedicado a lo que se califica de «primeras manifestaciones del republicanismo asturiano», supone en primer lugar una gran síntesis del período comprendido entre 1789-1833 del cual no se contaba que hasta este momento con una visión de conjunto de esta entidad. Lo más relevante es que define las características de aquel republicanismo circunstancial, de aquellos individuos aislados que tenían afinidades con la masonería y que muchos de ellos estuvieron exiliados (de ahí la importancia de la prensa del exilio así como los libros procedentes del extranjero). En lo concerniente al período 18331868, un tiempo marcado por la represión, por la censura, por la presencia 
del carlismo -y comparto la opinión del autor de que el carlismo asturiano «demanda un buen estudio con urgencia»-, en el cual ya se vislumbran los primeros grupos demorrepublicanos organizados, ya sea en la universidad, en cafés y casinos, en sociedades de socorros mutuos y en sociedades secretas, así como la acción de masas anónimas que se manifiesta en distintos motines de subsistencias. Paso a paso, aumentará la visibilización de lo que Sánchez Collantes denomina demorrepublicanismo, que progresivamente da señales de vida con la creación de comités en distintos núcleos asturianos y con materiales $\mathrm{y}$ actividades de propaganda «en aquel tiempo ominoso [cuando] reinaba el silencio de la tumba».

El segundo bloque de esta primera parte puede resumirse con el título del primer epígrafe del mismo: «Euforia, propaganda y desencanto tras la Gloriosa». A más libertad, más propaganda; ello queda atestiguado por la documentación utilizada por Sánchez Collantes, que da cuenta de cabeceras de prensa, catecismos, opúsculos varios, etc., así como de la actividad electoral, que pasará a ocupar muchas de las páginas del libro. Los procesos electorales, la implantación del republicanismo federal, la propaganda y la movilización republicana y los intentos insurreccionales protagonizan este segundo bloque. No es un dato menor que muchos de los protagonistas de esos movimientos y de esas actividades seguirán siéndolo en las décadas siguientes, de ahí la importancia de la investigación prosopográfica realizada por el autor, a pesar de que él mismo se lamente que pueda implicar una lectura farragosa para quienes se acerquen a las páginas de El pueblo a escena.

El tercer y último bloque de esta primera parte está dedicado a los años previos a la proclamación de la I República, a la I República y a los inicios de la Restauración. En este período tiene lugar la segunda guerra carlista, que tuvo especial incidencia en Asturias como bien refleja el profesor Sánchez Collantes. Estos años convulsos disponen de investigaciones fuera de Asturias, especialmente para lo que concierne a las limitaciones de las iniciativas que se intentaron desarrollar durante la I República y sobre las que el autor realiza el consiguiente balance. También hay espacio para el cantonalismo y si bien Asturias no formó parte de la geografía cantonal del verano de 1873, pues este fenómeno no se produjo en las zonas con fuerte presencia carlista, sí hubo un cantonalismo «rezagado» en Asturias, lo que es menos conocido y que tuvo un componente masónico en los levantamientos armados que se produjeron y del cual ahora podemos saber más gracias al rastreo «al detalle» realizado por las fuentes disponibles. Acaba este bloque el autor sumergiéndose en los movimientos hacia la restauración borbónica que se beneficiaron del cansancio generalizado en el que estaban sumidos los republicanos, del 
papel desarrollado por la Iglesia y por el Ejército, así como del miedo al efecto dominó que podría provocar la Comuna de París, cuestión que permitiría al doctor Sánchez Collantes analizarlo en términos de pánico moral mas no lo interpreta de este modo.

En mi opinión, la primera parte del libro está conformada por las páginas que más pueden atraer al lector no familiarizado con las historia de las culturas políticas republicanas, pues por ellas desfilan auténticas biografías de novela, matadores de reyes, motines, logias, pasquines, detenciones, insurrecciones, gabinetes de lectura e incluso personajes inmortalizados por Benito Pérez Galdós, con una narración que no puede calificarse de tediosa, tal y como sí hace el propio autor de pasajes de la segunda parte de la obra.

La segunda parte del libro, «La configuración política de la diversidad republicana (1874-1890)», comprende 316 páginas que hacen de la misma la parte más extensa de la obra. Dividida en tres bloques, el título del primero de ellos, «Tiempos de clandestinidad y los márgenes de la legalidad», no puede ser más elocuente sobre su contenido. A pesar de los testimonios sobre el escaso entusiasmo que provocó el regreso de la monarquía, en Asturias también se produce una rápida adhesión a la misma de Iglesia, Ejército y Diputación, cambios de calles y retirada de símbolos políticos, desaires y polémicas con motivo de visitas reales, fraccionamiento de un republicanismo que sufre la ilegalidad así como un fuerte grado de personalismo en su seno. Frente a esta situación, que también lleva aparejados exilio, hostigamiento y represión, los republicanos buscan espacios alternativos de sociabilidad, utilizan eufemismos para mantener su actividad pública y apuestan por fórmulas unitarias como la Unión Democrática (que colocaría a la capital asturiana en la vanguardia de la democracia). Sánchez Collantes se sumerge en la letra más pequeña de distintas fuentes (cartas, sueltos de prensa, suscripciones, donativos, etc.) para mostrar los distintos caminos que tomó la reorganización republicana, cerrando este bloque con un epígrafe dedicado al levantamiento republicano que se produjo en el concejo de L.lena en febrero de 1880 y que él emparenta con buen tino con las insurrecciones románticas que se produjeron durante el Sexenio en pro de la República federal.

El segundo bloque, "Cristalización de un republicanismo plural (18811885)», es un recorrido pormenorizado por la reorganización de las distintas familias republicanas desde que se permite la actividad de las mismas en 1881. Los procesos electorales, las polémicas locales (como la portuaria gijonesa), la creación de nuevos espacios de sociabilidad y la escisión en el seno del federalismo son solo algunos de los temas tratados. Considero que son de especial interés aquellas cuestiones no tan bien conocidas sobre las que el autor aporta 
luz; me refiero al federalismo coalicionista liderado por Jaime Martí-Miquel, al poder movilizador de los impulsos coalicionistas, a la Asociación Republicana Militar y a lo que Sánchez Collantes califica de «republicanismo vergonzante», esto es, las redes clientelares republicanas que se valían del sistema caciquil imperante.

El tercer y último bloque de esta segunda parte, «Consolidación y estrategias de los republicanismos (1886-1890)», ahonda en aspectos ya reflejados en el bloque anterior, como los triunfos republicanos en elecciones municipales, las polémicas portuarias, las disidencias en el federalismo o el efecto movilizador que tuvieron las tesis coalicionistas hasta en los lugares más recónditos de Asturias. Otros temas investigados y reflejados en este bloque son el texto de la Constitución federal del Estado asturiano, las conexiones con la Asamblea Nacional Republicana, la emergencia de nuevas fuerzas republicanas y la solidaridad con presos y exiliados.

La tercera parte, dedicada a "Las bases sociales de la democracia republicana en la Asturias del ochocientos», puede llevar a cierto engaño por sus cerca de setenta páginas, pero no debería obviarse que multitud de referencias relacionadas con el contenido esta parte salpican los cientos de páginas que la anteceden. Sánchez Collantes realiza un repaso exhaustivo a través del cual refleja la heterogeneidad de las bases sociales republicanas, confirmando su fuerte componente obrero y la presencia testimonial del mismo en los órganos de dirección de las fuerzas republicanas. Si bien esto ya se vislumbraba en estudios anteriores, no sucedía lo mismo respecto a los republicanos que ocupaban oficios tradicionales y que vivían en zonas rurales. Quizás se eche en falta al llegar a este punto partes semejantes pero referidas a la socialización política de las mujeres republicanas o a cómo las culturas políticas republicanas desarrollaron un corpus literario, musical e icónico propio, que si bien también aparecen más o menos señalados a lo largo del libro también podrían constituir bloques propios y particularizados dentro del mismo.

La obra finaliza con las conclusiones del autor que, si bien pueden ser esencialmente compartidas, quiero hacer hincapié en una que no debería pasar desapercibida: conocer los entresijos de la cultura política republicana es fundamental para conocer la Asturias del siglo XIX, así como de las primeras décadas del XX. El pueblo a escena es una demostración excelente en dicho sentido. 